\title{
Does It Make a Difference? Relations of Institutional Frameworks and the Regional Provision of Continuing Higher Education in England and Spain
}

\author{
Diana Treviño-Eberhard * and Katrin Kaufmann-Kuchta * \\ German Institute for Adult Education Leibniz Centre for Lifelong Learning, 53175 Bonn, Germany \\ * Correspondence: diana.trevino-eberhard@outlook.de (D.T.-E.); kaufmann-kuchta@die-bonn.de (K.K.-K.)
}

check for

updates

Citation: Treviño-Eberhard, D.;

Kaufmann-Kuchta, K. Does It Make a

Difference? Relations of Institutional Frameworks and the Regional Provision of Continuing Higher Education in England and Spain. Educ. Sci. 2022, 12, 132. https:// doi.org/10.3390/educsci12020132

Academic Editors: Regula Julia Leemann, Kriesi Irene and Rita Nikolai

Received: 30 October 2021 Accepted: 14 February 2022 Published: 18 February 2022

Publisher's Note: MDPI stays neutral with regard to jurisdictional claims in published maps and institutional affiliations.

Copyright: (C) 2022 by the authors. Licensee MDPI, Basel, Switzerland. This article is an open access article distributed under the terms and conditions of the Creative Commons Attribution (CC BY) license (https:// creativecommons.org/licenses/by/ $4.0 /)$.

\begin{abstract}
In this research, we compare interrelations between institutional settings and regional provision structures of continuing higher education (CHE) in England and Spain. The aim of the qualitative analysis is to identify and to compare country-specific linkages between national and regional policies, legal and financial regulations and their impact on providers, types of provision and target groups of CHE at the regional level. Theoretical assumptions of educational governance, environmental neo-institutionalism, and the sociology of conventions guide the analysis, based on expert interviews in England and Spain. Our research questions are: What modes of coordination of action to provide $\mathrm{CHE}$ are caused by national and regional regulations in England and Spain? How are these actions justified, and how do they influence regional CHE provision types and target groups in both countries? Interview-based findings show that national and regional regulations embrace hybrid modes of coordination of action regarding CHE provision in both countries. Specifically, centralised national policies in England and a mixture of centralised and decentralised legal frameworks in Spain impact regional CHE provision by universities, as does the scope of university autonomy in both countries. However, national frameworks only explain regional disparities in CHE provision to a limited extent. Less formal normative dimensions and social orders of university orientations and labour market demands also influence regional types of provision, concepts, provider cooperation, and adult $\mathrm{CHE}$ learners.
\end{abstract}

Keywords: continuing higher education; international comparison; expert interviews; governance; institutional analysis; regional coordination of action

\section{Introduction}

Within the field of European higher education, countries have long been asked to widen access for mature learners to universities respectively higher education institutions (HEIs). In England, universities are subsumed under the term Higher Education Institutions. "Higher education institution [ ... ] currently means any provider which is one or more of the following: a UK university; a higher education corporation; an institution designated as eligible to receive support from funds administered by the Office for Students (OfS), aside from a further education college." [1]. As we focus on universities only, we refer to the term universities. However, wide variation in the participation of adults in continuing higher education $(\mathrm{CHE})$ between countries remains [2]. Comparative research on $\mathrm{CHE}$ - understood as a subdomain of adult continuing education (ACE) provided by universities - traces this back to country-specific interrelations of national educational policies, conceptualisations, target groups, and provider structures of $\mathrm{CHE}$ within multi-level education systems. Meanwhile, country studies demonstrate the difficulty of comparing and explaining interactions of institutional embeddings, governing actors, and provider structures of CHE between countries [3-5]. This complex interplay is also shaped by differing regulatory frameworks of $\mathrm{ACE}$, higher education (HE), and vocational education and training (VET), leading to hybrid organisational provision structures [6]. Capturing central 
governance modes and how they impact regional provision of $\mathrm{CHE}$ becomes more challenging due to regional differences in the implementation of legal regulations and modes of funding for adult learning programmes [7]. Details regarding national frameworks and how they pave the way for specific forms of regional action coordination of CHE provision remains a research desideratum [8].

The variety of institutional patterns that we see in CHE on the macro-level across countries implies that concepts, provision, providers, and target groups on the meso-level are influenced by interactions of state and non-state stakeholders at national and regional levels. In this contribution, we perform a comparative analysis of national institutional frameworks and their implications for regional CHE providers and provision structures in two European countries, thus, facilitating country comparisons of CHE systems. Accounting for complex CHE governance systems and focusing on universities in England and Spain, we analyse the relations of national respectively regional institutional embeddings (legal and financial regulations) and how they shape regional provision structures (providers, provision, and target groups) in the countries. For this, we consider regional structures on the basis of selected universities in both countries and focus on one autonomous community (AC) in Spain. The leading questions are: What modes of coordination of action to provide CHE are caused by national and regional regulations in England and Spain? How are these actions justified, and how do they influence country-specific regional CHE provision types and target groups?

Section 2 provides an overview of the main country-specific institutional characteristics of CHE. Section 3 introduces the theoretical framework. Section 4 describes the methodological design. Section 5 presents the findings of our analysis and compares prevalent national frameworks and modes of coordination of action and their implications for regional CHE provision structures for the two countries. Section 6 determines whether the identified linkages between differing national institutional frameworks and regional CHE provision structures can be useful for further cross-country comparisons of governance analysis of $\mathrm{CHE}$ systems.

\section{Institutional Characteristics of CHE in England and Spain}

Ex ante to our analysis, we describe institutional characteristics of CHE that are relevant to the research question. Therefore, we focus on the state of research in England and Spain regarding influences of HE policies, centralised and decentralised legal and financial governance modes of $\mathrm{HE}$ and provision and target groups of $\mathrm{CHE}$.

\subsection{National Frameworks, Provision and Target Groups of CHE in England}

The European Union (EU) has lost influence on HE in England, where the national HE framework reflects an inward-looking HE system $[9,10]$. References to EU policies within current national HE and CHE frameworks and policies in England are not made [8]. However, England shows a strong focus on a national widening participation strategy (WPS) and thereby adheres to the policy objectives of the European Research Area to widen participation actions in HE. The current governance mode for HE and CHE in England, including the WPS, is characterised by hierarchical centralised regulations and neoliberal public management processes [8]. At the same time, the national HE legal framework and the Higher Education and Research Act 2017 [11] enable strong autonomy of universities to implement degree-related CHE offerings. However, a strong national HE regulator in England — the Office for Students (OfS) — was introduced by this legislation. Among other things, the OfS controls the implementation of the WPS. On the basis of this legislation, $\mathrm{CHE}$ is embedded in traditional HE offerings. Adults as target groups for HE are addressed by the WPS, which aims to increase access to HE for underrepresented groups, including mature students. The strategy suggests financial incentives to encourage universities to admit underrepresented groups [12]. However, universities are free to decide which underrepresented group to focus on. Research shows that in a market oriented, competitive HE system such as England, universities tend to develop similar strategies to 
ensure less socially selective access to HE [12]. It appears that universities predominantly offer full-time HE programmes for younger students and fewer part-time programmes targeting mature students [12]. In addition, the WPS policy promotes a collaborative, local approach of provision, including universities, further education colleges (FECs), local authorities and employers, and thereby supports pathways of mature learners to HE [13]. Nevertheless, opportunities for participation of underrepresented and disadvantaged students remain unequal across England as national WPS initiatives depend on varying university admission processes in regional contexts $[10,14,15]$.

\subsection{National Frameworks, Provision and Target Groups of CHE in Spain}

In Spain, HE and CHE programmes such as those aligning universities as providers of Lifelong Learning (LLL) within the 'Third Mission of universities' [16,17] are shaped by EU policies. References to EU policies within current national HE and CHE frameworks and policies in Spain are strong and CHE is framed by a decentralised, soft HE framework and different forms of university governance in regional units [8,17]. In contrast to England, the current HE governance is decentralised and shared between the central state and regional authorities. Furthermore, $\mathrm{CHE}$ is not embedded in traditional HE offerings. As in England, however, universities' autonomy regarding the provision of CHE is strong and depends on the university's autonomy status, as enacted in the national royal decree 822/2021 of HE [18]. In general, CHE provided by Spanish universities addresses working adults and their professional development for the labour market [17,19]. The universities themselves describe this provision as lifelong-learning and offer their own non-official HE degrees, so-called títulos propios [17]. This HE provision is less degree-related and, as part of the 'Third Mission', is not officially recognised by the Spanish government $[17,20]$. Currently, a national agreement between two consultative bodies, the Council of Universities and the Conference of Rectors of Spanish Universities, standardises CHE offerings across all universities according to the duration of courses and ECTS across all Spanish universities [21,22]. The agreement defines 'títulos propios' as postgraduate degrees, and diplomas or university extension certificates as shorter degrees. Whereas títulos propios target university students with an undergraduate degree, shorter degrees are often aimed at people without a degree [21]. Both types are usually self-financed through course fees and designed for working students. However, due to the autonomous and decentralised HE system, public universities regulate $\mathrm{CHE}$ through their internal university rules and often provide it autonomously or in collaboration with stakeholders from the labour market or companies [21]. Additionally, public universities in Spain offer HE access programmes for adults. They are regulated by centralised national HE rules and define different HE entrance conditions to officially accredited HE degrees, targeted at different age groups [19].

\subsection{Research Desiderata}

Research for both countries illustrates that national and regional regulations and the degree of universities' autonomy have an influence on the provision of CHE. However, how university autonomy is applied in both countries remains unexplained, as does how legal and financial regulations and regional features influence regional CHE provision. Primarily due to a lack of data, it has not yet been clarified how regional characteristics and the coordination of action between, and legitimations of, different $\mathrm{CHE}$ providers influence types of CHE offerings and target groups. This is apparent in England, where national regulations provide a clear framework for $\mathrm{CHE}$, while individual universities are empowered to engage with CHE provision differently. The same applies to Spain, where decentralised soft regulations and universities' autonomy to implement CHE offerings in cooperation with stakeholders of the labour market play a crucial role.

In order to deepen the understanding of how national governance interacts with and influences regional $\mathrm{CHE}$ provision, we compare coordination of action and justifications related to CHE provision in England and Spain. We focus on interrelations between national 
and regional regulations and policy frameworks (macro-level) and the provision, providers, and target groups of $\mathrm{CHE}$ (meso-level) within regional settings of universities offering $\mathrm{CHE}$.

\section{Theoretical Framework}

To analyse the interrelations of macro- and meso-level CHE governance systems in the countries, we build on a theoretical framework based on assumptions of the educational governance perspective and features of HE [23-25]. A full review of literature regarding HE governance modes and how they frame basic governance of CHE in England and Spain goes beyond the scope of this paper. Here we would like to refer to results of previous research $[8,26,27]$. Additionally, we use the explanatory powers of the environmental neo-institutionalism and the sociology of conventions. Accounting for the complexity of levels and actors involved in governing $\mathrm{CHE}$, the educational governance perspective helps to focus on actor constellations and their coordination of action in multi-layered CHE systems [28]. We argue that national regulations frame interrelations of state and non-state related actors of CHE and their central modes of coordination of action, such as hierarchy, market, community, and networks $[29,30]$. We refer to hierarchical coordination of actions by means of top-down regulations using legal measures and distribution of earmarked resources. Such bureaucratic decision-making powers of state authorities and departments determine the supervisory power of members of the CHE system [29,31]. By contrast, market-guided coordination of action refers to self-regulated actions between actors of CHE in which goods (e.g., financial goods, participants, or social reputation $[29,30]$ ) are exchanged via supply and demand in a competitive market system. Community and network-oriented coordination of actions describes more affective and voluntary-based collective actions between actors, whereas community driven modes are based on shared values and are often initiated by social associations, or scientific or professional CHE communities [30,32]. Network-oriented coordination of actions arises through negotiations and voluntary agreements between independent actors, which often combine public goals and community related interests (e.g., policy networks and cooperation of private companies) [32-34].

Since the degree of universities' autonomy in English and Spanish HE systems is relevant for the provision of $\mathrm{CHE}$, we add the classic modes of coordination of action by the dimension of autonomy. Autonomy is often related to financial issues (e.g., whether to procure funds from own revenues, third-party funds, or tuition fees) and to the ability of universities to define study structures and contents and to regulate student admission and student profiles [35,36]. Although action coordination often represents hybrid forms of such ideal types (hierarchy, market, community, networks, and autonomy), the analytical categories allow the identification of complex forms of action coordination between actors and providers within country-specific institutional CHE settings.

When analysing the linkages between institutional settings, coordination of actions and the provision of $\mathrm{CHE}$, the institutional neo-institutionalism offers a helpful perspective [37]. This lens provides assumptions about the behaviour of organisations and takes their institutional embedding into account. Organisations adapt to their institutional environment by referring to regulative (e.g., formal and informal laws), normative (e.g., values and desirable goals) and cultural-cognitive (e.g., cultural conceptions and frameworks) rules to secure their resources and legitimacy [38]. The distinction of these types of institutional rules explains organisational behaviour with reference to different aspects of institutional logics [38]. Such rules can specify the modalities of CHE coordinating action in the regional contexts of universities.

To a deeper extent, the sociology of conventions allows the identification of central frames of reference for actors' actions and, thus, illuminates which normative processes respectively conventions impact and direct the coordination mechanism of actors within regional provision of $\mathrm{CHE}$. Actors draw on these conventions (civic, market, industrial, fame, domestic, and project/network [39-41]) as evolved orders of justification, worth and logics of action in a socio-cultural environment. We assume that although CHE governance 
implied by national and regional frameworks influences provision by universities, it might be justified by different conventions. For example, the civic convention justifies $\mathrm{CHE}$ programmes by claiming educational equality and integration. The market and industrial convention is often used to legitimise competition for students and orientations towards degree-related and standardised educational offerings for labour market requirements. The convention of fame reveals the public prestige and status of universities within the $\mathrm{HE}$ system. The domestic convention relies on proven in-house practices and quality standards of universities to justify admission to their CHE programmes. Similar to the coordination of action networks, the project/network convention is evident when universities provide flexible $\mathrm{CHE}$ offerings by cooperating and networking with other $\mathrm{CHE}$ providers in order to strengthen their position in the CHE market $[40,41]$. This conventionalist view helps to explain regional actions of universities to offer $\mathrm{CHE}$ and to address specific target groups in England and Spain.

\section{Methodological Design}

We apply a qualitative contrastive case study design with England and Spain as analytical cases. Case studies help to simultaneously observe similarities and differences within policy contexts and how these policies develop in specific locations [42]. Comparing the country-specific CHE institutional frameworks and provision structures identifies both contrastive governance features between the cases, and any of their typical cross-country characteristics. With this analysis we do not claim to generalise the results of our country comparison; we would like to provide theory-based information which can facilitate further cross-country comparisons. As demonstrated in Section 2, we chose countries which share common and contrastive characteristics of national institutional frameworks and provision types of CHE. The countries differ in their HE governance regulations and funding features, concepts, types of provision, and addressed target groups of CHE. At the same time, both countries are western industrialised nations and OECD members embedding CHE within their HE system, empowering universities to implement $\mathrm{CHE}$ within regional demands.

On the basis of the state of research, we firstly did a country-specific document analysis of legislative texts and key papers on $\mathrm{CHE}$ financing mechanisms to capture governance modes and actors involved in regulating, financing, and providing $\mathrm{CHE}$. This enabled us to identify governance related actors and university experts in different regional contexts for our interview sample. To account for country-specific features and to ensure comparability between the countries, we interviewed additional experts in an exemplary region in Spain where $\mathrm{HE} / \mathrm{CHE}$ is regulated within autonomous communities (ACs). Overall, we conducted guideline-based expert interviews with central actors at both institutional levels (macro- and meso-level). Experts are defined as persons who have special and exclusive knowledge due to their professional position.

Following the multi-level approach, we chose national and regional bodies of the political decision-making system, funding and research organisations, charities, and representatives of CHE providers. To ensure thematic comparability, we designed a researchquestion-based interview guide for both countries with identical key questions, partially modifying aspects for the specifics of each country. Results of the analysis of eight expert interviews in England and seven in Spain build our empirical base. Data collection took place between October 2019 and July 2021. The interview data were analysed using structured qualitative content analysis [43]. Accordingly, text segments were mapped to categories of a deductive/inductive formed code system by two researchers, each working separately with the transcripts, allowing the assessment of consistency between their codings [44]. We used key expert statements for both countries of the following superordinate categories of the code-system: general statements about the system; national and regional rights of disposal and legislation; national and regional financing; coordination of action by hierarchy, market, community, networks, and autonomy; provision. Superordinate categories were inductively further divided into sub-categories. We analysed the categories of coordination of action with a particular focus on distinct types of institutional rules 
and convention-related contents. Finally, contents of the categories were summarised and provide the basis of our results presented in Section 5, illustrated by key expert statements.

\section{Analysis and Comparison of Regional CHE Provision in England and Spain}

In Sections 5.1 and 5.2, we describe the modes of action coordination to provide $\mathrm{CHE}$ caused by national and regional regulations (macro-level) in England and Spain. We analyse how these actions are justified and how they influence country-specific regional CHE provision types and target groups (meso-level). In Section 5.3, we compare the results for both countries.

\subsection{Regional CHE Provision in England}

In England, CHE is not universities' main business; its provision is embedded within the traditional HE framework. The leading policy is the OfS's WPS, through which the government seeks to increase opportunities for (among others) mature learners without prior HE qualifications to enter and succeed in HE. This WPS funding is oriented towards civic social logics, as this HE state actor remarks:

So, through the access and participation work, we're perhaps interested in how mature students intersect with other characteristics of students, which means that they have experienced disadvantage. We also provide funding to universities, really to get them to do things that they wouldn't do on their own. (ENG_9_CHE_expert_nat_gov, line 28-31)

The WPS also reflects both a strong, degree-related, hierarchical HE funding system related to student enrolment, and the government's focus on qualifications and social cohesion for all HE participants. This focus implies a reference to the industrial convention, legitimising provision on the basis of standardised HE qualifications:

So, the funding comes via the students in that way, and it's quite restrictive in terms of the mode the student has to be in, and it assumes that everything's going to be degree-shaped. (... It means that universities are incentivised to get the students they know are going to stick for a whole degree (... ). (ENG_10_CHE_prov_nat_pub, line 117-122)

Regulations and hierarchical state funding incentives exist to widen access to HE. The policy reflects justifications based on a mixture of the civic and industry convention. However, universities can adapt autonomously to this WP policy approach, adjusting HE access offerings based on marketized coordination of actions and the market convention to recruit mainly young, full-time students. This market-oriented action of universities to provide $\mathrm{CHE}$ is in conflict with the civic logic of the widening access policy line to expand access for mature students to HE. One university expert explains that in order to provide $\mathrm{CHE}$ they need to operate as a business following market logics:

There's a business model that works very straightforwardly. You get ( . . ) economies of scale with a critical mass of fulltime students. Part-time students/adults often want to study part-time because they're in work or they have caring responsibilities. ( . . . ) So, in my view, there are quite a lot of incentives for universities to focus on young students rather than on mature students because the business model is easier to make work for young students. (ENG_9_CHE_expert_nat_gov, line 83-92)

Against this trend to recruit young students, universities also provide HE access to adult learners in orientation to the civic convention in response to regional student demands.

(...) things are very regional in Britain (...) in [region 1] for example there are 32 universities, amazing. In [region 2] of England, it's about three. So again, there's a difference in access so I think that universities will probably respond differently across the regions. (ENG_13_CHE_prov_nat_pub, line 30-32)

Some universities are explicitly oriented towards local needs and align their strategy according to the region's structural development, e.g., by increasing the share of university 
graduates, including for employed and older people. The following quote of a university in a deprived area shows how they justify CHE provision in order to comply with the civic convention of equal access and individuals' integration into HE:

The (...) adult learning thing is about supporting the university's desire to engage with as many adults - both in work and not in work-and help build progression and transition pipelines into our university. (ENG_4_CHE_prov_nat_public, line 38-39)

Here, normative rules and the civic convention seem to guide universities' provision of CHE. However, normative rules based on logics of the civic and project/network convention also impact $\mathrm{CHE}$ provision. Coordination of action via networks can be demonstrated by the WPS implementation by a [university engaged in flexible, part time provision]. The university provides flexible evening courses and part-time provision to reach their students. They define non-traditional students (NTS) as people from low socio-economic groups with no prior qualification for entering HE. To recruit and support mature and local student progression into HE, the university partners with FECs and community and third sector providers:

Widening participation is all about advising and improving attainment to go to university. Our work is much broader than that. We come in and work with community groups, colleges, third sector organisations, trade unions and we build (...) long and deep partnerships. (...) Whereas most universities work with school children. (ENG_13_CHE_prov_nat_pub, line 48-51)

However, this network coordination is not only based on the civic convention, it is also viable for the university in terms of market-related criteria. Students who participate in a HE course at a locally accessible further education college (FEC) often move on to a collaborating university, as a certificate from the university might seem more valuable than a certificate from the FEC. Therefore, FECs represent "participation hotbeds" (ENG_13_CHE_prov_nat_pub, line 80) for the university to recruit local learners.

Finally, to widen access to $\mathrm{HE}$, universities also refer to the convention of fame to legitimise their focus on certain target groups. They use subject-specific one year HE gateway programmes such as foundation years, year zero programmes, or access diplomas to give students the A-level qualifications they need to advance to degree-courses of $\mathrm{HE}$. Not all universities act the same way: Some aim for international research excellence, competing for the most promising students. In conflict with the civic convention stands the convention of fame as research excellence universities focus their WPS activities not on recruiting students from the university's local area, but on high qualified young, full-time students. Their focus is legitimised by their aim of attaining the best reputation in the HE system.

You've got [research excellence universities], top world leaders. You just have to wonder how much they're gonna put up with all this regulatory framework. (. . ) You know their view of higher education is global, they want to be one of the top ten of the international universities. They don't care about the local very much at all, so it's a real pest to them to be involved in widening participation. (ENG_4_CHE_prov_nat_public, line 111-115)

Overall, the interview analysis for England indicates that universities adapt to the WPS within regions on the basis of hierarchal, marketized, network-related and autonomous modes of coordination of action. These arise from national frameworks and are, thus, based on regulative rules. Meanwhile, universities implement the WPS autonomously in an increasingly marketized HE system. This indicates that normative rules also impact the type of regional CHE provision by means of universities' reference of orientation, such as international league tables and regional environments. Overall, conflicting university actions can be explained by a mixture of the civic, industrial, market convention and sometimes by the convention of fame and project/network. 


\subsection{Regional CHE Provision in Spain}

Spanish universities mainly offer CHE via non-official HE degrees, which are not regulated by the rigid quality assurance proceedings of official HE degrees. According to the national HE framework, universities can autonomously provide self-funded and less degree-related HE outside traditional bureaucratic and hierarchical regulations. The national HE law also regulates HE access exams for adults aged 25, 40, or 45. This seems to be guided by a mixture of industrial and civic social logics. The aim is to guarantee equal access via standardised entry conditions. Despite common guidelines for nonofficial HE degrees and access opportunities for NTS, universities provide types of CHE offerings autonomously and apply their own HE entrance requirements within the ACs. Unlike England, regional HE regulations and government priorities have an impact on the provision of CHE by universities. Especially, regulative rules such as regional university statutes and regional administration by means of labour market demands determine the provision of non-official HE degrees. Thus, the type of regional CHE provision within the universities' autonomous scope is guided by regulative rules and is often justified by marketized and industrial social logics. Experts explain that non-official HE degrees are designed under the competitive influence of large companies and are strongly oriented to regional labour market demands. This also applies to the $\mathrm{AC}$ analysed in this research. One AC regional university states skills and employment as actual aim of $\mathrm{CHE}$, referencing LLL in its statute they define CHE as:

(... ) any lifelong learning activity, with the aim of improving knowledge, skills and attitudes, a personal, critical or social perspective related to employment and improvement of the quality of life. (ESP_9_CHE_prov_reg_pub, line 43-45)

Though the university provides non-official HE degrees mainly for graduates or working adults to address regional labour market demands, regarding the type of study the university is relatively inflexible, competing for students with large companies that offer their own CHE programmes. This is reflected in an expert's illustration of how a mixture of informal regulative and normative rules on the basis of the market and industrial convention impacts CHE provision:

The employers in $[A C]$ ask us to put pressure on the university to accept more (..) students in IT or digital skills because there are many more companies that require those training and skills competencies. So I think that now there is much more interest in adults who do this type of training and I think they do it through Google or Amazon (... ) these companies offer you specific skills and they give you these certificates that here sometimes have almost more value than the degree of a non-regulated education in a Spanish university. (ESP_9_CHE_prov-reg-pub, line 59-72)

The [regional university of the $\mathrm{AC}$ ] does not seem to meet the labour market demands. The provision of non-official HE degrees often arises on the basis of initiatives by faculty members; it is not the main business of the university. In addition, the non-official HE degrees should be self-financed. To increase flexibility and obtain financial support for non-official HE degrees, the university works with regional administrations and companies. The following quote illustrates that demand for non-official HE degrees stems not from the university's internal stakeholders, but from informal regulations orientated towards regional public administrations and market requirements:

Because obviously the studies themselves are first born as a need that university professors may be seeing in their field of action. Sometimes they also come about as a result of demands that may come from companies or even from the public administration. (ESP_9_CHE_prov-reg-pub, line 74-79)

The self-financing model of non-official HE degrees impacts provision because offers are mainly justified by labour market demands and target working adults. This is not only the case for the [regional university of the AC]. Universities in other ACs also reference more informal regulative rules and orientations towards the market convention to offer 
non-official HE degrees for profession-oriented and regional labour market demands. An expert cites results of a recent study of the University Network of Postgraduate Studies and Lifelong Learning:

(...) a study this year about continuing higher education offerings provided by universities (...) showed that (..) the average age (. . ) is around 30 ( . . ). We also address people who have finished their studies and who want to specialise in something. (ESP_12_CHE_net_nat_cso, line 43-48)

Besides non-official HE degrees, Spanish universities provide other CHE offerings, such as 'university of the third age', micro-credentials or dual master-degrees, the latter enhancing provision of $\mathrm{HE}$ and vocational training. The impact of a mixture of regulative and normative rules on the basis of the market and civic convention becomes evident here. Universities aim to provide CHE in terms of orientation towards public regional demands, as reflected in the following quote:

(...) perhaps the situation is quite different from university to university. In my university it's a result of the public demands to the [regional] government. People did massive demonstrations to have the [traditional university strongly engaged in LLL]. So we are very socially engaged. This forces us to do this kind of social offer. (ESP_7_CHE_expert_nat_gov, line 33-39)

Regarding the provision of $\mathrm{CHE}$, universities seem to face conflicts which are caused by the market convention on the one hand and the civic convention on the other hand. Universities need to cooperate with labour market players in order to comply with the self-funding model of CHE, but also need to engage socially to meet public demands of the regional government. Summarising empirical findings for Spain, the national and regional CHE framework implies autonomous and marketized coordination of action between $\mathrm{CHE}$ actors and providers. Universities act autonomously in order to provide non-official HE degrees and other CHE offerings and justify provision mainly in relation to the industrial and market convention. They search for regional co-funders (e.g., regional government administrations or companies) and compete for students with companies providing their own CHE programmes. In contrast to England, the formal and informal regulative rules via university statutes and strong orientations towards regional labour market demands seem to be the dominant type of institutional frameworks for universities. Normative rules on the basis of the civic convention which seems to stand in conflict with the market and industrial convention play a role as universities' provision is also oriented towards their mission to engage socially, though to a more limited extent than in England. Overall, the regional provision of CHE in Spain is characterised by autonomous and marketized coordination of action and framed by regulative and, to a lesser extent, normative rules. The more concrete legitimisation to provide regional $\mathrm{CHE}$ in terms of non-official $\mathrm{HE}$ reveals a strong orientation towards the industrial and market convention.

\subsection{Comparison of Regional CHE Provision in England and Spain}

The empirical findings for both countries show that distinct national institutional frameworks for $\mathrm{CHE}$ within the HE system (macro-level) influence universities' regional provision of CHE (meso-level). In both cases, the frameworks include the scope of HE autonomy which is decisive for regional implementations of $\mathrm{CHE}$. Crucial is also the mode of funding $\mathrm{CHE}$, leading to fundamental differences in governance and the convention referred to for justification between the countries. On this basis, universities orient towards different institutional rules and social conventions to provide CHE offerings and address target groups. The following table (Table 1) represents an overview, compiling the state of research and the results for England and Spain. 
Table 1. Comparative overview of national frameworks and regional CHE provision in England and Spain.

\begin{tabular}{|c|c|c|c|}
\hline \multirow{16}{*}{ 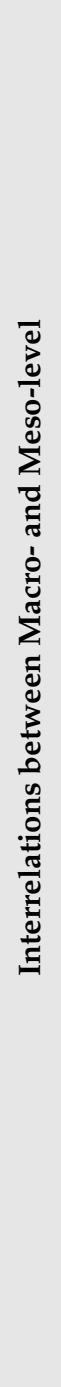 } & Institutional Setting of CHE & England & Spain \\
\hline & National framework & $\begin{array}{l}\text { Little EU influence; } \\
\text { WPS to secure equal HE access to } \\
\text { underrepresented, mature, and } \\
\text { disadvantaged students; } \\
\text { CHE as integrated area in HE }\end{array}$ & $\begin{array}{l}\text { Strong EU influence; } \\
\text { HE legislation to secure HE access to } 25,40 \text {, } \\
45 \text { year students; } \\
\text { CHE as separate area of HE }\end{array}$ \\
\hline & National funding & $\begin{array}{l}\text { Funding incentives for degree-related HE } \\
\text { provision for underrepresented } \\
\text { target groups }\end{array}$ & $\begin{array}{l}\text { Self-financing of non-official HE degrees } \\
\text { expected for working adult target groups }\end{array}$ \\
\hline & Regional framework & No regional HE framework & Regional HE laws and university statutes \\
\hline & Regional funding & No regional HE funding; No other funding & $\begin{array}{l}\text { No regional HE funding for non-official HE } \\
\text { degrees; Co-funding models via regional } \\
\text { ministries and companies }\end{array}$ \\
\hline & Regional provision of CHE & England & Spain \\
\hline & Action coordination & Hierarchy; Market; Autonomy; Network & Hierarchy; Autonomy; Market \\
\hline & Degree of autonomy & $\begin{array}{l}\text { Authority to award official HE degrees; } \\
\text { Autonomy to implement WPS regarding } \\
\text { the type of offering and target groups }\end{array}$ & $\begin{array}{l}\text { Authority to award official and non-official } \\
\text { HE degrees; Autonomy to implement } \\
\text { non-official HE degrees regarding the type } \\
\text { of offering and target groups }\end{array}$ \\
\hline & Institutional rule & Regulative; Normative & Regulative; Normative \\
\hline & Convention & $\begin{array}{l}\text { Civic; Industrial; Market; Fame; } \\
\text { Project/Network }\end{array}$ & Market; Industrial; Civic \\
\hline & Providers & $\begin{array}{l}\text { Universities; Distance Learning } \\
\text { Universities; Further Education Colleges }\end{array}$ & $\begin{array}{l}\text { Universities; Distance Learning } \\
\text { Universities; Companies }\end{array}$ \\
\hline & Concept of provision & Widening access programmes to $\mathrm{HE}$ & HE access exams; Non-official HE degrees \\
\hline & Type ofaccess requirement & $\begin{array}{l}\text { A-levels; Year zero programmes; } \\
\text { Foundation courses; Access diplomas }\end{array}$ & HE access exams \\
\hline & Type ofindividual funding & WPS funding for universities & Self-financing of universities \\
\hline & Type of provision & $\begin{array}{l}\text { Degree-related HE; Continuing } \\
\text { professional development courses; } \\
\text { Community based learning activities; } \\
\text { University of the third age }\end{array}$ & $\begin{array}{l}\text { Regionally valid non-official HE degrees; } \\
\text { Dual Master degrees; Micro-credentials, } \\
\text { University of the third age }\end{array}$ \\
\hline & Type of target groups & $\begin{array}{l}\text { Diverse groups of students; Focus in many } \\
\text { cases on younger full-time students, } \\
\text { but also on mature part-time students with } \\
\text { no prior HE access qualification }\end{array}$ & $\begin{array}{l}\text { Similar groups of students; Focus on } \\
\text { employed adults with prior HE } \\
\text { qualification studying in full- or part-time; } \\
\text { HE access exams for adults aged } 25,40,45\end{array}$ \\
\hline
\end{tabular}

Provision of CHE in England is understood as an integrated area of HE. However, within the WPS, the aim is to secure equal access to HE for NTS, including mature students. The WPS and related funding incentives of the OfS provide funding attached to the enrolment of mature students within degree oriented HE provision. This shows that CHE provision in England is characterised by a hierarchical and market-oriented coordination of action. However, due to strong university autonomy and orientations towards normative rules based on mainly the civic and market convention, the WPS is implemented differently in regions respectively single universities in terms of type of offers and target groups addressed. Especially the scope of autonomy allows universities to define their own orientations to focus on CHE concepts and mature target groups, thereby increasing equal access, or the number of traditional or high-class student profiles. This mixture of regulative rules (e.g., WPS regulation and funding) and normative rules (e.g., university orientation on international league tables or NTS) is reflected in distinct types of CHE offerings and target groups. Overall, it is evident that national formal frameworks in England shape the scope of CHE provision of universities. Due to the WPS funding framework attached to the enrolment of mature students within degree oriented HE provision, universities mainly seem to rely on contradictory conventions such as the mixture of the civic and market convention and this explains why many universities provide for example foundation courses. Nevertheless, the WPS also gives rise to less formal frameworks that need to be taken into 
account, as they allow universities to orient towards the convention of the market and fame and are, thus, crucial in explaining regionally different recruitments of young or mature students for their CHE offerings.

In contrast, $\mathrm{CHE}$ in Spain is governed by national HE legislation, which embeds $\mathrm{CHE}$ as a type of non-official and less degree-related HE provision separately from official $\mathrm{HE}$ degrees. Access to HE for NTS is not controlled by a WP policy, but by legally defined HE entrance requirements for different age groups. The national legal framework expects non-official HE to be self-financed and allows universities to develop their own offerings. This broad autonomy explains CHE provision guided by profit-oriented regional labour market needs for working adults. Additionally, regional HE legislation of the ACs in terms of university statutes manifest the hierarchical and marketized mode of coordination of action to provide CHE. The university statutes seem to reinforce linkages of non-official HE degrees with labour market requirements at the regional level and, therefore, strongly rely on the industrial and market convention. Thereby universities are mainly guided by formal regulative rules (e.g., national HE frameworks and university statutes) and informal regulative rules (e.g., regional required skills for labour market demands). The missing of a widening access policy in $\mathrm{HE}$ and the existing legal framework which expects non-official HE to be self-financed, can explain hybrid and conflicting coordination of action characterized mainly by market and industrial but also civic logics to provide CHE. It explains why the autonomously implemented market-oriented offerings appear to lead to similar CHE offerings by means of non-official HE degrees and a common focus on working adult target groups between universities. As in England, informal frameworks need to be taken into account in order to explain regional provision of CHE in Spain.

\section{Conclusions}

The aim of this paper is to ascertain whether it makes a difference how national institutional frameworks are linked to regional provision types and target groups of $\mathrm{CHE}$ in England and Spain. We identified the modes of coordination of action to provide CHE caused by national institutional frameworks on the macro-level. We also elaborated how these actions are justified and how they influence types of regional CHE provision and universities' target groups. Drawing on a theory-guided country comparison, we then explained the differences of $\mathrm{CHE}$ coordination mechanisms resulting from national and regional legal frameworks in England and Spain. Roughly summarising our country case study, we can say that depending on the governance system of the national HE framework for universities to provide CHE offerings (macro-level), the regional provision of $\mathrm{CHE}$ and addressed target groups differ (meso-level). The neo-institutionalism and the sociology of convention help to explore to what extent the national framework reinforces certain conventions and how these are referred to in the context of university autonomy. Thereby the theoretical approaches help to explain at the meso-level how and why CHE offers are provided differently and address diverse target groups at the regional level.

The main difference between the two countries on the national level is the steering system of $\mathrm{HE}$ and $\mathrm{CHE}$. In England, $\mathrm{CHE}$ is integrated into HE offerings and only indirectly regulated by a national policy to widen access for underrepresented groups in HE (WPS). In Spain, HE and CHE is regulated decentrally by the ACs. Non-official HE provision relies on the autonomous scope of the universities. On the basis of these different national frameworks, distinct coordination of action arises and regional CHE provision is legitimised in reference to varying regulative and normative scopes. In England, the regulative and centralised WPS of the OfS encourages universities to implement funded widening access programmes. However, due to their autonomy in implementing regional widening access programmes, universities additionally refer to normative rules on the basis of the civic and market convention. Normative orientations towards equal access and the value of recruiting as many students as possible to secure university incomes justify diverse types of $\mathrm{HE}$ access programmes and the recruitment of young or mature student profiles. 
In Spain, on the other hand, regulative and standardised legislation enabling access for adults of different age groups exists only on a national level. In relation to $\mathrm{CHE}$ programmes, the national HE government allows universities to provide widening access programmes in the ACs and in their autonomous-scope non-official HE degrees. These degrees are supposed to be self-financed. Thus, universities orient towards normative rules, referring to regional labour market demands and justify CHE provision on the basis of the industrial and market convention. Due to this and the competition between universities and companies to provide $\mathrm{CHE}$, offerings mainly address similar adult working student profiles.

The interviews analysed in this paper show for both countries that national formal frameworks (e.g., policies or laws) only determine the regional provision of CHE by universities to a certain extent. Thus, the analysis of country-specific institutional frameworks of CHE by means of national regulations on the macro-level (e.g., WPS) is not sufficient to explain disparities in regional $\mathrm{CHE}$ provision. This means that a comprehensive governance analysis must also take into account less formal regional regulations and social orders, as universities in England and Spain are allowed to implement CHE offerings autonomously within the national HE frameworks. If a comprehensive governance analysis of countryspecific $\mathrm{CHE}$ systems is to understand how regional disparities in CHE provision appear, national policies and legal frameworks need to be considered alongside softer normative dimensions such as specific university orientations, regional adult learner profiles and skills requirements of the regional labour market.

At this point, we would like to point out that the empirical findings of this research are based on limited interview data. It is, thus, premature to draw general conclusions regarding causal relationships between national institutional frameworks and impacts on regional types of $\mathrm{CHE}$ provision. Nevertheless, the comparative table provides a theorybased frame which can facilitate further country-comparisons. To this end, further country and regional studies are needed to verify the less formal influencing factors of regional provision of $\mathrm{CHE}$ we have identified, and to analyse how strongly they cause regional disparities in CHE provision. This would reveal which indicators should be taken into account at a national and regional level and better facilitate country-comparisons of CHE governance in international comparative studies.

Author Contributions: Conceptualization, D.T.-E. and K.K.-K.; methodology, D.T.-E. and K.K.-K.; software, MAXQDA; validation, D.T.-E. and K.K.-K.; formal analysis, D.T.-E. and K.K.-K.; investigation, D.T.-E. and K.K.-K.; data curation, D.T.-E. and K.K.-K.; writing—original draft preparation, D.T.-E. and K.K.-K.; writing-review and editing, D.T.-E. and K.K.-K.; visualization, D.T.-E. and K.K.-K.; supervision, K.K.-K.; project administration, D.T.-E. and K.K.-K.; funding acquisition, German Institute for Adult Education Leibniz Centre for Lifelong Learning 53175 Bonn, Germany. All authors have read and agreed to the published version of the manuscript.

Funding: This research was funded by the German Institute for Adult Education Leibniz Centre for Lifelong Learning 53175 Bonn, Germany and the APC was also funded by the German Institute for Adult Education Leibniz Centre for Lifelong Learning 53175 Bonn, Germany.

Institutional Review Board Statement: Ethical standards of this study are in accordance with the Declaration of Ethics and approved by the Ethics Commission of the German Institute for Adult Education Leibniz Centre for Lifelong Learning 53175 Bonn, Germany.

Informed Consent Statement: Informed consent was obtained from all subjects involved in the study.

Data Availability Statement: Details regarding data supporting reported results can be requested at the German Institute for Adult Education Leibniz Centre for Lifelong Learning 53175 Bonn, Germany. Therefore, please contact Treviño-Eberhard, D. and Kaufmann-Kuchta, K. 


\begin{abstract}
Acknowledgments: We would like to express our gratitude to Ramón Flecha and Alan Tuckett for participating and assisting in this scientific study. Both aided us in the selection of experts for the interviews in Spain and England. This facilitated the gateway to the country-specific fields of ACE and CHE. Additionally, we thank very much the experts from England and Spain who participated in our guideline-based interviews. And finally, we would like to take this opportunity to thank the PhD student Anna Caroline Bernhardt, who is also involved in the research project, and our student assistant Lea Heck.
\end{abstract}

Conflicts of Interest: The authors declare no conflict of interest.

\title{
References
}

1. Eurydice. United Kingdom-England: Types of Higher Education Institutions. Available online: https://eacea.ec.europa.eu/ national-policies/eurydice/content/types-higher-education-institutions-91_en (accessed on 30 October 2021).

2. Souto-Otero, M.; Whitworth, A. Adult participation in higher education and the 'knowledge economy': A cross-national analysis of patterns of delayed participation in higher education across 15 European countries. Br. J. Sociol. Educ. 2017, 38, 763-781. [CrossRef]

3. Desjardins, R.; Ioannidou, A. The political economy of adult learning systems-Some institutional features that promote adult learning participation. Z. Weit. 2020, 43, 143-168. [CrossRef]

4. Dollhausen, K.; Wolter, A.; Lattke, S.; Scheliga, F.; Spexard, A.; Geffers, J.; Banscherus, U. Developing the Adult Learning Sector. Lot 3: Opening Higher Education to Adults. Contract EAC 2012-0074. Final Report; Publications Office of the European Union: Luxembourg, 2013. [CrossRef]

5. Hanft, A.; Knust, M. Comparative Overview of Study Results. In Continuing Higher Education and Lifelong Learning: An international Comparative Study on Structures, Organisation and Provisions; Knust, M., Hanft, A., Eds.; Springer: Dordrecht, The Netherlands, 2009; pp. 23-69. ISBN 978-1-4020-9675-4.

6. Dollhausen, K.; Lattke, S. Organisation und Organisationsformen wissenschaftlicher Weiterbildung. In Handbuch Wissenschaftliche Weiterbildung; Jütte, W., Rohs, M., Eds.; Springer VS: Wiesbaden, Germany, 2020; pp. 99-122. ISBN 978-3-658-28639-2.

7. Kenny, M.; Kinsella, M. Comparative analysis. In Policy Making in Adult Education: A Comparative Approach across 21 European Regions, 3rd ed.; Agentur für Erwachsenen- und Weiterbildung, Ed.; W. Bertelsmann Verlag: Bielefeld, Germany, 2016; pp. 95-110. ISBN 978-3-7639-5680-7.

8. Trevino-Eberhard, D.; Kaufmann-Kuchta, K. Regulation and Financing of Continuing Higher Education in England and Spain: A Comparison of Adult Education Governance Structures in National Contexts. Int. Jahrb. Erwachs. 2020, 43, 69-94. [CrossRef]

9. De Wit, H. The Bologna Process and the Wider World of Higher Education: The Cooperation Competition Paradox in a Period of Increased Nationalism. In European Higher Education Area: The Impact of Past and Future Policies; Curaj, A., Deca, L., Pricopie, R., Eds.; Springer International Publishing: Cham, Switzerland, 2018; pp. 15-22. ISBN 978-3-319-77406-0.

10. Sapir, A. Widening participation policy as practice: Category work and local policy appropriations at student support units. J. Educ. Policy 2021, 1-21. [CrossRef]

11. House of Parliament. Higher Education and Research Act 2017. Chapter 29. Norwich. 2017. Available online: https://www. legislation.gov.uk/ukpga/2017/29/contents/enacted (accessed on 30 October 2021).

12. Evans, C.; Rees, G.; Taylor, C.; Wright, C. 'Widening Access' to higher education: The reproduction of university hierarchies through policy enactment. J. Educ. Policy 2019, 34, 101-116. [CrossRef]

13. Centenary Commission on Adult Education. "A Permanent National Necessity ... ": Adult Education and Lifelong Learning for 21st Century Britain; School of Education, University of Nottingham: Nottingham, UK, 2019; pp. 1-61. ISBN 978-0-9565448-2-7.

14. Hoskins, K.; Ilie, S. Widening Participation to Underrepresented and Disadvantaged Students. In Bridges, Pathways and Transitions; Shah, M., Whieford, G., Eds.; Elsevier: Amsterdam, The Netherlands, 2017; pp. 87-102. ISBN 978-00-8101-921-4.

15. O'Sullivan, K.; Byrne, D.; Robson, J.; Winters, N. Who Goes to College via Access Routes? A Comparative Study of Widening Participation Admission in Selective Universities in Ireland and England. Soc. Incl. 2019, 7, 38-51. [CrossRef]

16. Belando-Montoro, M.R. Aprendizaje a lo largo de la vida. Concepto y componentes. Rev. Iberoam. Educ. 2017, 75. [CrossRef]

17. De la Torre, E.M.; Perez-Esparrells, C.; Casani, F. The Policy Approach For The Third Mission Of Universities: The Spanish Case (1983-2018). Reg. Sect. Econ. Stud. 2018, 1, 13-30. [CrossRef]

18. Boletín Oficial del Estado. Real Decreto 822/2021, de 28 de Septiembre, Por el Que se Establece la Organización de las Enseñanzas Universitarias y del Procedimiento de Aseguramiento de su Calidad. Num. 233. Madrid. 2021. Available online: https: / / www.boe.es / buscar/doc.php?id=BOE-A-2021-15781 (accessed on 17 January 2022).

19. González-Monteagudo, J.; Padilla-Carmona, M. Políticas educativas en España y en Europa para estudiantes universitarios vulnerables y no tradicionales. In Políticas Públicas y Administración en Educación y Formación: Ejemplos en Países Latinoamericanos, Caribeños y Europeos; Walker, G.J.G., Vazquez, E.A., Lafont, P., Eds.; Editorial de la Universidad Autónoma de Yucatán: Yucatán, Mexico, 2017; pp. 211-233. ISBN 978-607-9490-41-6.

20. Sianes-Bautista, A.; Llorent-Vaquero, M. Estudiantes Universitarios 'no tradicionales' en España y Alemania: Un estudio Comparativo. In IX Congreso Iberamericano de Docencia Universitaria (Chair); Escudero, J.M., Vallejo, M., Eds.; La Universidad en Cambio: Gobernanza y renovación pedagógica; Universidad de Murcia: Murcia, España, 2016; pp. 804-808. 
21. Red Universitaria de Estudios de Posgrado y Educación Permanente. Informe de Resultados de la Encuesta Sobre la Situación Actual de los Títulos Propios en las Univeridades Españolas. Va-lencia. 2021. Available online: https://ruepep.org/wp-content/ uploads/2021/04/estudio_TTPP_2021-1.pdf (accessed on 30 October 2021).

22. Consejo de Universidades. La Formación Permanente y las Universidades Espanolas. Madrid. 2010. Available online: https:/ / ruepep.org/wp-content/uploads/2017/05/2010-formacion-permanente-universidades-espanolas.pdf (accessed on 30 October 2021).

23. Schemmann, M. Analysis of the governance of university continuing education in the United Kingdom and Germany. Int. Jahrb. Erwachs. 2014, 37, 61-71. [CrossRef]

24. Schrader, J. Governance in adult and further education: Unified Germany as a case study. Eur. Educ. 2010, 41, 41-66. [CrossRef]

25. Boeren, E. Understanding adult lifelong learning participation as a layered problem. Stud. Contin. Educ. 2017, 39, 161-175. [CrossRef]

26. Capano, G.; Pritoni, A. Varieties of hybrid systemic governance in European Higher Education. High. Educ. Q. 2018, 73, 10-28. [CrossRef]

27. Dobbins, M.; Knill, C. Reformen der Hochschulsteuerung in Europa: Konzepte, Messung und empirische Befunde. In Wirtschaftsund Sozialpolitik. Internationalisierte Welten der Bildung: Bildung und Bildungspolitik im Globalen Vergleich, 1st ed.; Schmid, J., Amos, S.K., Schrader., J., Eds.; Nomos: Baden-Baden, Germany, 2016; pp. 33-78. [CrossRef]

28. Maag Merki, K.; Altrichter, H. Educational Governance. In Educational Governance als Forschungsperspektive: Strategien. Methoden. Ansätze, 2nd ed.; Maag Merki, K., Langer, R., Altrichter, H., Eds.; Springer: Dordrecht, The Netherlands, 2014; Volume 17, pp. 396-410. ISBN 978-3-658-06442-6.

29. Altrichter, H. Theory and Evidence on Governance: Conceptual and Empirical Strategies of Research on Governance in Education. Eur. J. Educ. 2010, 9, 147-158. [CrossRef]

30. Kussau, J.; Brüsemeister, T. Educational Governance: Zur Analyse der Handlungskoordination im Mehrebenensystem der Schule. In Educational Governance: Handlungskoordination und Steuerung im Bildungssystem, 1st ed.; Altrichter, H., Brüsemeister, T., Wissinger, J., Eds.; VS Verlag für Sozialwissenschaften: Wiesbaden, Germany, 2007; Volume 1, pp. 15-54. ISBN 978-3-531-15279-0.

31. Döhler, M.1.2 Hierarchie. In Handbuch Governance: Theoretische Grundlagen und Empirische Anwendungsfelder; Benz, A., Lütz, S., Schimank, U., Simonis, G., Eds.; VS Verlag für Sozialwissenschaften: Wiesbaden, Germany, 2007; pp. 46-53. ISBN 978-3-531-14748-2.

32. Lange, S.; Schimank, U. Governance und gesellschaftliche Integration. In Governance und Gesellschaftliche Integration; Lange, S., Schimank, U., Eds.; VS Verlag für Sozialwissenschaften: Wiesbaden, Germany, 2004; pp. 9-44. ISBN 978-3-8100-4134-0.

33. Wald, A.; Jansen, D. Netzwerke. In Handbuch Governance: Theoretische Grundlagen und Empirische Anwendungsfelder; Benz, A., Lütz, S., Schimank, U., Simonis, G., Eds.; VS Verlag für Sozialwissenschaften: Wiesbaden, Germany, 2007; pp. 93-105. ISBN 978-3-531-15279-0.

34. Dupriez, V.; Maroy, C. Regulation in school systems: A theoretical analysis of the structural framework of the school system in French-speaking Belgium. J. Educ. Policy 2003, 18, 375-392. [CrossRef]

35. Bennetot Pruvot, E.; Estermann, T. University Autonomy in Europe iii: The Scorecard 2017; European University Association: Brussels, Belgium, 2017; Available online: https:/ / www.eua.eu/downloads/publications/university\%20autonomy\%f20in \%20 europe \%20iii\%20the\%20scorecard\%202017.pdf (accessed on 30 October 2021).

36. Dobbins, M.; Knill, C.; Vögtle, E.M. An analytical framework for the cross-country comparison of higher education governance. High. Educ. 2011, 62, 665-683. [CrossRef]

37. DiMaggio, P.J.; Powell, W.W. The Iron Cage Revisited: Institutional Isomorphism and Collective Rationality in Organizational Fields. Am Sociol. Rev. 1983, 48, 147-160. [CrossRef]

38. Scott, W.R. Institutions and Organizations. In Foundations for Organizational Science, 2nd ed.; Sage Publications: Thousand Oaks, CA, USA, 2001; ISBN 9780761920014.

39. Boltanski, L.; Thévenot, L. On Justification: Economies of Worth; Princeton University Press: Princeton, NJ, USA, 2006; ISBN 978-0-691-12516-9.

40. Leemann, R.J.; Imdorf, C. Das Potenzial der Soziologie der Konventionen für die Bildungsforschung. In Bildung und Konventionen; Imdorf, C., Leemann, R.J., Gonon, P., Eds.; Springer Fachmedien: Wiesbaden, Germany, 2019; pp. 3-45. ISBN 978-3-658-23300-6.

41. Gonon, P. Zur Legitimität von Hochschulweiterbildung in der Schweiz-Zwischen Wissenschafts- und Arbeitsmarktorientierung. In Bildung und Konventionen; Imdorf, C., Leemann, R.J., Gonon, P., Eds.; Springer Fachmedien: Wiesbaden, Germany, 2019; pp. 371-399. ISBN 978-3-658-23300-6.

42. Yin, R.K. Case Study Research: Design and Methods, 4th ed.; Sage: Newbury Park, CA, USA, 2009 ; ISBN 9781412960991.

43. Schreier, M. Qualitative Content Analysis in Practice, 1st ed.; Sage Publications Ltd.: London, UK, 2012; ISBN 978-1849205931.

44. Kuckartz, U.; Rädiker, S. Analyzing Qualitative Data with MAXQDA: Text, Audio, and Video; Springer International Publishing: Cham, Switzerland, 2019; ISBN 978-3-030-15670-1. 